\section{Students' Psychosocial Empowerment With The 'Steps For Life' Personal and Social Skills Greek Elementary Programme}

\author{
Ntina Kourmousi ${ }^{a}$, Georgios Markogiannakis ${ }^{b}$, Chara Tzavarac, \\ Kalliope Kounenou ${ }^{d}$, Achilleas Mandrikase, Efstathia Christopoulouf, \\ Vasilios Koutras
}

\author{
Received: 16 February 2018 \\ Revised: $\quad 10$ April 2018 \\ Accepted: 09 May 2018 \\ ISSN: 1307-9298 \\ Copyright @ IEJEE \\ www.iejee.com
}

DOI: 10.26822/iejee.2018541303

\begin{abstract}
Significant research has been conducted on skills' enhancement school programs, since their importance has been well established. The presented study evaluates "Steps for life", a Greek, universal, annual, teacher-taught programme, designed to improve personal and social skills in young elementary students by the use of questions, diffusion in formal and hidden curriculum, and parental involvement. The experimental study was conducted in Greece during 2013-2014. The sample consisted of 2439 students, with 1516 forming the experimental group and 923 the control group. The study questionnaire included demographics, Personal and Social Skills Scale-Elementary, and the BASE scale. It investigated students' self-esteem, concentration of attention, participation/cooperation, emotions' identification and expression, emotions' management, ability to control verbal and physical aggressiveness, ability to control victimization, empathy, friendship skills, problem-solving, ability to take responsibility, and use of spoken and written language. The experimental group exhibited significant improvement in all investigated skills post-intervention, while the control group did not improve concentration of attention, emotions' management, and their ability to control verbal and physical aggressiveness and victimization. The analysis also revealed that intervention students had significantly higher improvement than the controls in all dimensions. Appropriately designed mental health promotion programs can improve several children's social-emotional skills and abilities.
\end{abstract}

Keywords: Personal \& Social Skills, Social-Emotional Skills, Mental Health Promotion, Programme Evaluation, Elementary Curriculum.

\section{Introduction}

It has almost been forty years since Gilbert Botvin (1979) created the first life skills school programme and paved the way for social and emotional evidence-based skill's education. Since then, the differences between the closely linked and often overlapping approaches of prevention and mental health education and promotion have been clarified, with the distinction between them laying in their targeted outcome (WHO, 2002): Prevention, having to do with the causes of disease (Herrman, Saxena, Moodie \& World Health Organization, 2005) aims to help in the avoidance of problems or the reduction of symptoms related to mental health (WHO, 2002), and mental health promotion, having to do with the determinants of mental health (Herrman, Saxena, Moodie \& World Health Organization, 2005), is a process of empowering individuals in increasing control over their mental health and the factors that determine it (WHO, 2004a).

Also, since then, several mental health-related school programmes have been well-recognized, either categorized as Life Skills (LS), Skills for Life (SFL), Personal and Social Skills, and Social and Emotional Skills (SES), or labeled as Prevention, or Social Emotional Learning (SEL) programmes. Whatever their title and specific goals, or even their theoretical basis, one cannot help but admit that this kind of education has produced impressive outcomes during the past decades concerning the improvement of students' social, emotional, and coping skills, as pointed out by international organizations (UNESCO, 2004; WHO, 2003) and shown by various meta-analyses (Durlak, Weissberg, Dymnicki, Taylor \& Schellinger, 2011; Diekstra \& Gravesteijn, 2008; Payton et al., 2008; Wilson, Gottfredson \& Najaka, 2001; Durlak \& Wells, 1997). Such programmes have been found to a) improve self-esteem (O'Mara, Marsh, Craven \& Debus, 2006; Haney \& Durlac, 1998), b) prevent depression (Merry, McDowell, Hetrick, Bir \& Muller, 2004; Forness, Serna, Kavale \& Nielsen, 1998) and other mental health problems (Greenberg, Domitrovich, \& Bumbarger, 2001), c) prevent drug use (Faggiano et al. 2005; Tobler et al., 2000) and alcohol and tobacco use (Botvin, Griffin, Paul, \& Macaulay, 2003), d) enhance emotion management and self-control (Gansle, 2005; Barrett, 2004; Kusché \& Greenberg, 1994), e) help children resolve interpersonal conflicts (Geller, 1999; Grossman et al., 1997; Kusché \& Greenberg, 1994; Shure \& Spivack, 1982) and maintain healthy relationships (Beelmann \& Lösel, 2006; Englander-Golden, Jackson, Crane, Schwarzkopf \& Lyle, 1989) and e) reduce violent behavior (Hahn et al., 2007; Wilson \& Lipsey, 2007; Wilson, Lipsey \& Derzon, 2003; Catalano, Berglund, Ryan, Lonczak, \& Hawkins, 2004).

However, despite all the attention and the plethora of such programmes, WHO (2010) acknowledged the fact that "the vast majority of studies have been done in high-income countries, with the evidence base dominated by studies in the United States." (p. 30), and urged researchers to con-

\footnotetext{
aCorresponding Author: Ntina Kourmousi, School of Pedagogical \& Technological Education (ASPETE), Athens, Greece. E-mail: nkourmousi@yahoo.com

'Georgios Markogiannakis, University of Ioannina, Department of Early Childhood Education, Ioannina, Greece. E-mail: gewmark@gmail.com 'Chara Tzavara, Department of Hygiene, Epidemiology and Medical Statistics, Medical School of National and Kapodistrian University of Athens, Greece. E-mail: htzavara@med.uoa.gr

'Kalliopi Kounenou, Department of Education, School of Pedagogical \& Technological Education (ASPETE), Athens, Greece.

Email: kkounen@aspete.gr

e Achilleas Mandrikas, 56th Prefecture of Primary Education of Attica, Eastern Attica Directorate of Primary Education, Athens, Greece E-mail: amandrik@otenet.gr

${ }^{f}$ Efstathia Christopoulou, 40th Prefecture of Primary Education of Attica, D Directorate of Athens' Primary Education, Athens, Greece. E-mail: echristop64@gmail.com

g Vasilios Koutras, Department of Early Childhood Education, University of Ioannina, Ioannina, Greece. E-mail: vkoutras@cc.uoi.gr
} 
duct studies in "different settings, particularly in low-and middle-income countries" (p.30). Greece does consist a different setting, especially due to its economic situation; though it is not officially defined as a low or even a middle income country, its economy has declined substantially since the beginning of an economic crisis which became apparent in 2009, leading to unemployment, poverty, and major cut-downs in health and education sectors' financing. In this country, research concerning prevention and social-emotional education in elementary school is extremely limited; there are but a very few effectiveness evaluation studies, to our knowledge: a) a study of a conflict control programme with structured activities named "You and I become WE" which was found to improve social skills in fifth and sixth graders (Chiementi \& Triliva, 1994) and is no longer available for teachers to implement, b) a presentation of four briefly described studies on intervention programmes which were designed by the Center for Research and Practice of School Psychology of the National and Kapodistrian University of Athens and found to promote resilience, well-being, academic achievement and positive climate in the school setting (Hatzichristou \& Lianos, 2016), c) a study of a programme found to tackle racism in students of second to fifth grade (Triliva, Anagnostopoulou, \& Vleioras, 2014), d) a study of a programme integrating life skills in a sports context which was found to enhance life skills in fifth and sixth graders (Papacharisis, Goudas, Danish, \& Theodorakis, 2005), and e) an evaluation study of a pilot and rather concise curriculum named "School and Social Life" which was created under the auspices of the Greek Paedagogical Institute (renamed to Greek Educational Policy Institute), -was officially implemented nationally in specific schools only during the school-years of 2011-12 until 2015-16, and was found to improve students' emotional intelligence and academic performance (Babalis, Tsoli, Artikis, Mylonakou-Keke, \& Xanthakou, 2013).

The presented study examines the effectiveness of the elementary version of "Steps for life" -a Greek, universal, teacher-taught mental health promotion school programme for first and second grade students - which was designed having taken into account: a) the above mentioned WHO prompts, b) the fact that the Greek Official Curriculum declares all students' social and emotional development as one of its main goals (Ministry of Education and Religious Affairs 2003a; Ministry of Education and Religious Affairs, 2003b) but does not provide tools to help the teachers achieve it, c) that Greek Paedagogical University Departments (4 years of undergraduate studies in order to get a degree as a teacher) do not include social-emotional education as a subject and therefore teachers do not know how to teach it, and d) that no evaluated structured curricula exist for social-emotional skills' enhancement in elementary students of the first and second grades. We designed and conducted the presented experimental study, in order to identify a school-based approach which would improve Greek students' personal and social skills. We hypothesized that the students who would attend the "Steps for life" programme for one school-year, would have greater improvement compared to the ones who would attend the existing formal Greek curriculum concerning the taught, targeted and investigated skills: i) concentration of attention, ii) participation/cooperation in class, iii) emotions' identification and expression, iv) emotions' management, v) ability to control verbal and physical aggressiveness, vi) ability to control victimization, vii) empathy, viii) friendship skills, ix) problem-solving ability, $\mathrm{x}$ ) ability to take responsibility, and xii) use of spoken and written language,

\section{The "Steps for Life" Curriculum}

\section{Aim and theoretical basis of the programme}

The "Steps for Life" Elementary- aims to enhance first and second grade students' self-esteem, empathy, and personal and social skills, with an emphasis on emotion management and problem-solving. The programme does not intend to teach the children 'what to do' or 'how to behave', since it refrains from didacticism. Instead, by the almost sole use of questions during teaching, it guides the students in learning how to think for themselves, in order to reach their own conclusions and find their own solutions to their everyday problems.

"Steps for Life" Elementary-curriculum was created having taken into consideration the teaching and learning conditions in Greek Schools, the official Greek Elementary School Curriculum, and the knowledge offered by various SES and SEL programmes, approved by WHO and SAMHSA (e.g. Barrett, 2004; Committee for Children, 2002; Shure, 2000; Botvin, 1998; Kusché \& Greenberg, 1994; TACADE/ Lions, 1990; Borba, 1989), but cannot be described as culturally specific. The programme was designed in order to be implemented within "The Flexible Zone", which, according to the Greek educational system, is a weekly two hour period, during which Greek teachers can voluntarily choose to teach "Health Education", "Environmental Education", or "Cultural Education" (Ministry of Education and Religious Affairs 2003a; Ministry of Education and Religious Affairs, 2003b). "Steps for Life" is currently being implemented in several elementary classes throughout the country within the context of Health Education, after having been approved by the Greek Ministry of Education (Ф.14/816/171442/Г1/12-11-2013 and Ф.14/820/211037/ $\Delta 1 / 24-12-2014)$.

Concerning its theoretical background, it combines several important elements and strategies from different approaches: As a mental health education programme, which includes a) role-modelling of the taught skills during the "hidden curriculum" (conveyance of norms which occurrs outside formal lessons) on the part of the teacher, and b) the student's attempt by role-playing, it draws from Bandura's Social Learning Theory (Bandura, 1997). The importance of adults' role-modelling in issues that concern health and mental health education has been well documented (e.g. Hills, King, \& Armstrong, 2007; Brown \& Ogden, 2004; Meichenbaum, 1977; Mize \& Ladd, 1990), since children have been found to prefer to imitate a behavior they see executed, rather than obey verbal suggestions. Role-playing has also been long found to be quiet effective in change of behavior and in empathy enhancement (e.g. Gerdes, Segal, Jackson \& Mullins, 2011; Culbertson, 1957; Staub, 1971; Clore, \& Jeffery, 1972). “Through engaging in roleplay, one may obtain insight into himself, may be able to learn to control his feelings or to develop new life skills", as Corsini states in "Role Playing in Psychotherapy" (p. 6, 2017).

As a programme almost solely taught by the use of questions, encouraging children to think and express their opinions and guiding them to problem-solve by estimating consequences, it also draws from the cognitive approach of Arend, Gove and Sroufe (1979) and from Shure and Spivack's work (1982), which was found to produce positive results in the enhancement of children's problem-solving ability (Shure \& Spivack, 2008). More analytically this particular approach prompts children to problem solve by helping them to adopt a certain way of thinking through a problem: a) problem recognition (What is the problem exactly? How/when/where,/why did it occur? Are things the 
way they look?), b) solution finding (How many solutions can be thought of?), c) estimation of consequences (What might happen in case of each solution?), d) choice of best solution (So which would be the best idea?), e) solution's execution planning (How can the idea be implemented?).

As a programme which seeks to alter student's ways of thinking and acting by changing teachers' and parents' approaches, it borrows from the Eco-Behavioral Systems Model (Weissberg, Caplan, Sivo, 1989). In anly case, mental health promotion school programmes have been found to be more effective when involving elements of parents' and teachers' relevant training (WHO, 2005).

As a programme which encourages students to explore their emotions - and motives and learn through the process of pleasant discovery, it incorporates elements from the Psychoanalytic Theory (Cho, 2009; Britzman, 1998). Other researchers have found those elements to be effective in the evaluation of similar programs (e.g. Kusché, 2002).

Finally, but as importantly, as a programme which requires the unconditional acceptance of the students by their teachers, and the use of active listening in order to encourage children to find their own solutions to their problems, it also draws from Carl Rogers' person-centered humanistic approach (1998). Evidence has shown that educators' empathy positively contributes to students' learning and performance (Roorda, Koomen, Spilt, \& Oort, 2011) and that the use of active listening is quite important in effective teacher-parents' communication (Lasky, 2000) - which is essential in skills development programmes -, as well as in teachers' own communicative skills McNaughton, Hamlin, McCarthy, Head-Reeves, \& Schreiner, 2008). The programme also builds on a structured model for emotional education, initially introduced by the "Steps for Life" K-curriculum, which is a programme designed for younger children aged 4-6 years, and which also teaches personal and social skills with emphasis to main emotions management (Kourmousi, Salagianni, Merakou, Tzavara, \& Koutras, 2017; Kourmousi, 2012). Specifically, a nine step question-based procedure included in the "Steps for Life" Elementary-curriculum described below ensures even difficult and complicated emotions' teaching in a safe way. The procedure could be characterized as mainly cognitive, since it is question-based, with a psychoanalytic perspective at the point where it encourages children to explore their experienced emotions

Table 1. "Steps for Life" Elementary-curriculum 9 steps procedure for safe emotions' teaching in elementary students

Indicative Questions

How do you think the child

1. Naming the emotion

in this picture feels? What is the name of the emotion?

How can you tell what he/ she feels? How are the

2. External recognition eyes, the eyebrows, the arms, the body posture, the color of the face, etc.?

Do you remember a time when you also felt ... (emo-

3. Internal recognition tion's name)? What did it feel like inside your body? (e.g. changes in heart rate, in breathing, etc.)

\begin{tabular}{ll}
\hline 4. Stages of emotion & $\begin{array}{l}\text { How do we say it when we } \\
\text { feel just a little bit of that } \\
\text { emotion? How about when } \\
\text { it grows? How about when } \\
\text { it is really strong? }\end{array}$ \\
\hline 5. Causes of emotion & $\begin{array}{l}\text { What things usually make } \\
\text { you feel ... (emotion's } \\
\text { name)? }\end{array}$ \\
\hline 6. Causes of emotion in & $\begin{array}{l}\text { What things do you think } \\
\text { that would make a mom } \\
\text { feel ... (emotion's name)? }\end{array}$ \\
How about a teacher? How \\
about a kindergartner? \\
How about a policeman? \\
How about a young refu- \\
gee? etc.
\end{tabular}

Curriculum description

The "Steps for Life" elementary curriculum consists of: a) the Teacher's Manual containing the theoretical basis of the programme and specific instructions for its implementation, b) the structured and analytical Lesson Guide which also ensures an easy implementation, c) two hand-puppets - a boy and a girl students - used to introduce most of the lessons and demonstrate the taught skills, d) 76 pictures which serve for the introduction of the subject in most lessons, and e) the Letters to the Family which inform parents of the taught skills and provide them with simple guidelines and indicative ways of dialoguing, thus supporting the continuation of the child's learning at home.

The "Steps for Life" annual universal elementary curriculum consists of 27 two-hour weekly lessons, taught in a circle class arrangement, and divided into four modules: a) rule-setting and establishment of a good classroom climate, b) instruction of basic concepts, c) empathy and emotions' identification and management and d) prob- 
lem-solving and target-setting. Each lesson includes: i) the new concept, ii) the lesson goals, iii) the teaching instructions, iv) the needed materials, v) the introduction of the concept by puppet scenarios or by pictures vi) the discussion which contains all the questions which need to be asked, vii) the role-playing scenarios, viii) coursework activities, ix) suggested ways to transfer knowledge in the formal curriculum, $x$ ) suggested ways for the dissemination of the taught skills in the hidden curriculum (e.g. during free-activity time, break-time, and lunch time), and xi) the letter to the family, which describes the newly taught skills and includes suggestions and instructions for the consolidation of learning.

\section{Method}

\section{Research Design and Sampling Procedure}

The evaluation study took place in the school-year of 201314 in six Primary Education Districts of Attica - namely the prefecture in which Greece's capital, Athens, is located -, under the supervision of the University of Ioannina with the cooperation and support of the six District School Counselors in charge. The participating Primary Education Districts consisted of urban, rural, and even industrial areas, thus representing all area types. Furthermore, they also consisted of high, middle and low income areas, further strengthening the repreresentativeness of the sample.

The research design was experimental. Since the inter- vention aimed to evaluate the effectiveness of a universal programme whole classes and not students had to be randomly assigned in the experimental and control groups. Thus, regarding the sampling procedure, each School Counselor provided a list of willing to participate in the intervention first and second grade teachers from his/her district and conducted a draw between them in order to assign their students randomly in the experimental and control groups. A larger number of experimental group teachers was chosen, trying to ensure a large number even in case of possible dropouts. Control group teachers were promised that they would receive gratis both the curriculum package and the training during the next school year, while the experimental group teachers would be granted the material and the training during the year of the study. The draw identified seventy first and second grade teachers who became the experimental group's teachers. Forty-three colleagues of theirs became the control group's teachers, since 7 of the 50 ones who had initially been randomly assigned to that group dropped out during the pre and post intervention questionnaire completion, due to the time consuming procedure of completing one lengthy questionnaire for each of their students, as they reported

\section{Sample Size and Participant characteristics}

The sample consisted of 2439 first and second grade students, 1516 of which belonged to the intervention group and 923 to the control group. Sample characteristics of both study groups are presented in table 2 .

Table 2. Sample characteristics of the control and intervention group at baseline

\begin{tabular}{|c|c|c|c|}
\hline & $\begin{array}{c}\text { Control group } \\
(N=923)\end{array}$ & $\begin{array}{l}\text { Intervention group } \\
(N=1516)\end{array}$ & \\
\hline & $N(\%)$ & $N(\%)$ & $p+$ \\
\hline \multicolumn{4}{|l|}{ Gender } \\
\hline Boys & $471(51.0)$ & $766(50.6)$ & 0.823 \\
\hline Girls & $452(49.0)$ & $749(49.4)$ & \\
\hline \multicolumn{4}{|l|}{ Nationality } \\
\hline Greek & $771(88.7)$ & $1327(90.2)$ & 0.253 \\
\hline Other & $98(11.3)$ & $144(9.8)$ & \\
\hline \multicolumn{4}{|l|}{ Age } \\
\hline 6-7 у.о. & $396(43.7)$ & $690(46.6)$ & 0.163 \\
\hline 7-8 or more y.o. & $511(56.3)$ & $791(53.4)$ & \\
\hline \multicolumn{4}{|l|}{ Father's educational level } \\
\hline Primary to middle school & $66(10.8)$ & $142(14.0)$ & 0.166 \\
\hline High school & $188(30.8)$ & $302(29.9)$ & \\
\hline 2-year college/ University/ Post-graduate studies & $357(58.4)$ & $567(56.1)$ & \\
\hline \multicolumn{4}{|l|}{ Mother's educational level } \\
\hline Primary to middle school & $54(8.7)$ & $82(8.0)$ & 0.972 \\
\hline High school & $174(27.9)$ & $294(28.7)$ & \\
\hline 2-year college/ University/ Post-graduate studies & $395(63.4)$ & $649(63.3)$ & \\
\hline \multicolumn{4}{|l|}{ Parents living together } \\
\hline No & $86(10.4)$ & $156(11.7)$ & 0.362 \\
\hline Yes & $740(89.6)$ & $1179(88.3)$ & \\
\hline \multicolumn{4}{|l|}{ Number of siblings } \\
\hline None & $97(11.9)$ & $162(12.8)$ & 0.173 \\
\hline One & $423(51.7)$ & $691(54.7)$ & \\
\hline Two or more & $298(36.4)$ & $410(32.5)$ & \\
\hline
\end{tabular}


Table 2. (Cont.) Sample characteristics of the control and intervention group at baseline

\begin{tabular}{|c|c|c|c|}
\hline & $\begin{array}{c}\text { Control group } \\
(N=923)\end{array}$ & $\begin{array}{l}\text { Intervention group } \\
(N=1516)\end{array}$ & \\
\hline & $N(\%)$ & $N(\%)$ & $p+$ \\
\hline \multicolumn{4}{|c|}{ Attendance of full-time instead of classic course } \\
\hline No & $625(68.5)$ & 1054 (69.9) & 0.442 \\
\hline Yes & $288(31.5)$ & $453(30.1)$ & \\
\hline \multicolumn{4}{|c|}{ Attendance of an Integration Class/ Having Parallel Support } \\
\hline No & $870(96.3)$ & 1455 (96.4) & 0.923 \\
\hline Yes & $33(3.7)$ & $54(3.6)$ & \\
\hline \multicolumn{4}{|l|}{ Re-attendance of the same grade } \\
\hline No & $889(98.3)$ & $1478(98.0)$ & 0.562 \\
\hline Yes & $15(1.7)$ & $30(2.0)$ & \\
\hline Number of students in class, mean (SD) & $21.4(3.4)$ & $21.6(3.3)$ & $0.237++$ \\
\hline
\end{tabular}

The proportion of boys was $51 \%$ in the control group and $50.6 \%$ in the intervention one $(p=0.823)$. Both groups consisted mostly of Greek students (88.7\% in the control group and $90.2 \%$ in the intervention group). Children's age was similar in both groups, with the proportion of second graders being slightly larger than the one of the first graders. The majority of the children in both groups attended the classic-hour (8.30 a.m.-1.30 p.m.) course, as opposed to the full time one which operates from 7.30 a.m. to 4.00 p.m. Father's and mother's educational level as well as the number of siblings were similar in both groups, as was the living situation, since most children lived with both of their parents $(89.6 \%$ for the controls and $88.3 \%$ for the intervention group). Additionally, the proportion of those attending an integration class or receiving parallel support (thus students with special education needs), as well as the proportion of ones re-attending the same grade, were similar among the two groups. Also similar was the mean number of students in class. No intervention and control classes were in the same school.

\section{Facilitators' Training}

The experimental group's teachers became the facilitators of the curriculum. This practice is common regarding school-based prevention programmes, as reported in meta-analyses (e.g. Durlak et al., 2011; Diekstra \& Gravesteijn, 2008). In order to be trained, the intervention teachers attended: a) an initial presentation of the programme, during which the curriculum's guidelines and components were analytically presented to them, b) three whole-day bi-monthly experiential workshops, during which they were trained mostly in modeling and transferring the programme's skills in the hidden curriculum and c) monthly three-hour afternoon meetings with the coordinators, which provided them support throughout the implementation of the programme but also helped the researchers get feedback concerning implementation fidelity. The control group teachers did not receive any training.

\section{Implementation and Implementation Fidelity}

The experimental students attended the curriculum's structured two-hour lessons once a week, facilitated by their teachers. They also attended activities realized during dissemination in both the formal and hidden curriculum, throughout the week. At the same time, during the lessons that required so, their families received the programme's letters which contained guidelines concerning the continuation of learning of the taught skills.
Concerning the intervention's implementation fidelity, it should be stressed that the "Steps for Life" curriculum has the following characteristics which reinforce it:

1. Detailed implementation instructions are emphasized in the curriculum's Teacher's Manual.

2. Explicit guidelines included in the Lesson Guide describe the implementation of each lesson. Moreover, all the questions which the teacher has to ask his/her students, together with the indicative ways of dialoguing and the appropriate encouragement expressions for use during the course and during the hidden curriculum, are provided in the curriculum, fully formulated.

3. Every lesson of the "Steps for Life" curriculum is based on the knowledge acquired by the previous one; therefore it is practically impossible to implement lessons or activities randomly, without following the curriculum's proposed sequence.

Apart from the programme's characteristics, the following measures - similar to ones used in relevant studies (Brackett et al., 2012; Mishara \& Ystgaard, 2006; Flannery et al., 2003) - were taken in order to ensure implementation fidelity:

1. Clear and detailed implementation instructions were analytically discussed during the programme's initial presentation.

2. Experimental group's teachers had to complete an implementation and evaluation form after the completion of each lesson-teaching. The form, apart from questions concerning the students' concentration and interest, also asked the teachers to note the exact activities proposed by the Lesson Guide that they had realized and to describe any possible differences between the lesson as presented in the curriculum and the way it was carried out.

3. The six District School Counselors, who supervised the conduct of the study, visited their intervention schools on a weekly basis during the whole school-year, in order to inspect the implementation procedure, ensuring that the programme was taught as designed. 


\section{Measures}

The measure used to assess the intervention effectiveness was a questionnaire comprising a) questions which included demographics (sex, age, nationality, etc.), family information (e.g. if the child lived with both his parents in the same house, number of siblings, etc.) and school factors (e.g. if the student attended special education structures like an integration class or like having parallel support, etc.) b) the Personal and Social Skills Scale for Elementary Students Aged 7-9 (Kourmousi et al., 2017) which is designed to measure elementary students' personal and social skills in the school environment, and c) the Behavioral Academic Self-Esteem Scale (BASE) (Coopersmith \& Gilberts, 1982) which assesses students' self-esteem as exhibited by their behaviors in the school environment.

The Personal and Social Skills Scale for Elementary Students Aged 7-9 (Kourmousi et al., 2017) comprises 95 items which fall into eleven subscales, namely i) concentration of attention, ii) participation/cooperation in class, iii) emotions' identification and expression, iv) emotions management, v) ability to control verbal and physical ag gressiveness, vi) ability to control victimization, vii) empathy, viii) friendship skills, ix) problem-solving ability, x) ability to take responsibility, and xii) use of spoken and written language. It assesses the corresponding skills by examining the frequency of students' behaviors, as observed and rated by their teachers, with the use of a 7-point Likert-type scale, with answers ranging from 1=never or almost never, to $7=$ always or almost always. The scale was found to be a reliable and valid instrument for measuring Greek elementary students' personal and social skills, with acceptable Cronbach's alpha for all its subscales ranging from 0.82 to 0.92 (Kourmousi et al., 2017).

The BASE Scale (Coopersmith \& Gilberts, 1982) is also teacher-rated. It assesses students' self-esteem on the basis of the frequency of their behaviors, using a 5 point Likert scale ranging from $1=$ always to $5=$ never. It includes 16 items, which fall in five factors: student initiative, social attention, success/failure, social attraction, and self-confidence. The scale has been translated and adapted in Greek by Kakouros \& Maniadaki (2002).

\section{Ethical considerations}

The study questionnaire was anonymous. Permission to administer it to the teachers was granted by the Greek Institute of Educational Policy (Ref. Ф15/806/174250/Г1/1811-2013). Written consensus from each participating student's parents was collected prior to the completion of the corresponding questionnaire.
The study questionnaire was administered to both groups' teachers for completion before the intervention, with instructions to be completed within a week. The study questionnaire was also administered to all educators one month after the intervention completion, with the same as the above mentioned instructions.

\section{Results}

\section{Statistics and Data Analysis}

Quantitative variables were expressed as mean values (SD), while qualitative variables were expressed as absolute and relative frequencies. For the comparison of proportions chi-square and Fisher's exact tests were used. Continuous variables were tested for normality using the Kolmogorov-Smirnov criterion. Student's t-tests were computed for the comparison of mean values. Repeated measurements analysis of variance (ANOVA) was conducted to evaluate the changes observed in the questionnaire dimensions between the two study groups before and after the intervention. In order to control for effect of demographic data and school related characteristics a series of multiple linear regression analyses were conducted with dependent the change in each questionnaire dimension and independent variable the type of group (intervention vs. control), after adjusting for gender, nationality, age, father's and mother's educational level, living with both parents, number of siblings, attendance of an integration class or having parallel support, re-attendance of the same grade, school-hours (classic or all-day course), and number of students. Adjusted regression coefficients $(\beta)$ with standard errors (SE) were computed from the results of the linear regression analyses. Diagnostics for regression models were performed to check if the conditions for regression had been met with the residuals of each model being normally distributed and their variance being constant. Pearson correlation coefficients were used to explore the association between changes in dimensions of the questionnaire. All reported $\mathrm{p}$ values are two-tailed. Statistical significance was set at $p<.05$ and analyses were conducted using SPSS for Windows (Version 19.0. Armonk, NY: IBM Corp.).

\section{Changes in Questionnaire Dimensions}

Changes in questionnaire dimensions after the intervention completion for the two study groups are presented in table 3. At baseline, the control and intervention groups had similar scores on all dimensions. After the intervention, the experimental group students had significantly higher scores in all dimensions. The control group significantly improved most dimensions but did not perform

Table 3. Changes in questionnaire dimensions after the intervention completion for the two study groups

\begin{tabular}{|c|c|c|c|c|c|c|}
\hline & & Pre & Post & Change & & \\
\hline & Group & Mean (SD) & Mean (SD) & Mean (SD) & $\mathrm{P}++$ & $\mathrm{P} \ddagger$ \\
\hline \multirow[t]{3}{*}{$\begin{array}{l}\text { Ability to control Verbal and Physi- } \\
\text { cal Aggressiveness }\end{array}$} & Control & $5.88(0.99)$ & $5.90(1.02)$ & $0.02(0.66)$ & 0.353 & $<0.001$ \\
\hline & Intervention & $5.80(1.08)$ & $6.03(1.01)$ & $0.24(0.75)$ & $<0.001$ & \\
\hline & $\mathrm{P}+$ & 0.074 & 0.001 & & & \\
\hline \multirow[t]{3}{*}{ Problem-Solving Ability } & Control & $4.90(1.20)$ & $4.97(1.31)$ & $0.07(0.85)$ & 0.041 & $<0.001$ \\
\hline & Intervention & $4.86(1.22)$ & $5.31(1.28)$ & $0.55(0.95)$ & $<0.001$ & \\
\hline & $\mathrm{P}+$ & 0.430 & $<0.001$ & & & \\
\hline \multirow[t]{3}{*}{ Concentration of Attention } & Control & $5.14(1.42)$ & $5.14(1.50)$ & $0.00(1.02)$ & 0.756 & $<0.001$ \\
\hline & Intervention & $5.05(1.49)$ & $5.40(1.49)$ & $0.35(1.13)$ & $<0.001$ & \\
\hline & $\mathrm{P}+$ & 0.141 & $<0.001$ & & & \\
\hline
\end{tabular}


Table 3. (Cont.) Changes in questionnaire dimensions after the intervention completion for the two study groups

\begin{tabular}{|c|c|c|c|c|c|c|}
\hline & & Pre & Post & Change & & \\
\hline & Group & Mean (SD) & Mean (SD) & Mean (SD) & $\mathrm{P}++$ & $\mathrm{P} \ddagger$ \\
\hline \multirow[t]{3}{*}{ Participation/Cooperation } & Control & $5.26(1.04)$ & $5.35(1.06)$ & $0.09(0.72)$ & 0.001 & $<0.001$ \\
\hline & Intervention & $5.21(1.06)$ & $5.68(1.05)$ & $0.47(0.81)$ & $<0.001$ & \\
\hline & $\mathrm{P}+$ & 0.228 & 0.001 & & & \\
\hline \multirow[t]{3}{*}{ Empathy } & Control & $5.09(1.09)$ & $5.26(1.13)$ & $0.18(0.91)$ & $<0.001$ & $<0.001$ \\
\hline & Intervention & $5.07(1.11)$ & $5.70(1.11)$ & $0.63(0.97)$ & $<0.001$ & \\
\hline & $\mathrm{P}+$ & 0.686 & $<0.001$ & & & \\
\hline \multirow[t]{3}{*}{ Emotions' Management } & Control & $4.83(1.17)$ & $4.86(1.22)$ & $0.03(0.86)$ & 0.331 & $<0.001$ \\
\hline & Intervention & $4.76(1.22)$ & $5.17(1.25)$ & $0.41(0.98)$ & $<0.001$ & \\
\hline & $\mathrm{P}+$ & 0.133 & $<0.001$ & & & \\
\hline \multirow[t]{3}{*}{ Friendship skills } & Control & $5.27(0.90)$ & $5.37(0.92)$ & $0.11(0.69)$ & $<0.001$ & $<0.001$ \\
\hline & Intervention & $5.21(0.91)$ & $5.57(0.95)$ & $0.36(0.76)$ & $<0.001$ & \\
\hline & $\mathrm{P}+$ & 0.138 & $<0.001$ & & & \\
\hline \multirow[t]{3}{*}{ Ability to control Victimization } & Control & $6.22(0.93)$ & $6.29(0.87)$ & $0.02(0.66)$ & 0.381 & $<0.001$ \\
\hline & Intervention & $6.15(0.93)$ & $6.36(0.84)$ & $0.21(0.77)$ & $<0.001$ & \\
\hline & $\mathrm{P}+$ & 0.072 & 0.050 & & & \\
\hline \multirow[t]{3}{*}{$\begin{array}{l}\text { Emotions' Identification and } \\
\text { Expression }\end{array}$} & Control & $4.40(1.18)$ & $4.57(1.26)$ & $0.16(1.07)$ & $<0.001$ & $<0.001$ \\
\hline & Intervention & $4.34(1.11)$ & $5.01(1.20)$ & $0.67(1.16)$ & $<0.001$ & \\
\hline & $\mathrm{P}+$ & 0.186 & $<0.001$ & & & \\
\hline \multirow[t]{3}{*}{$\begin{array}{l}\text { Use of Spoken and Written } \\
\text { Language }\end{array}$} & Control & $4.78(1.21)$ & $4.93(1.24)$ & $0.16(0.77)$ & $<0.001$ & $<0.001$ \\
\hline & Intervention & $4.74(1.16)$ & $5.26(1.22)$ & $0.52(0.85)$ & $<0.001$ & \\
\hline & $\mathrm{P}+$ & 0.937 & $<0.001$ & & & \\
\hline \multirow[t]{3}{*}{ Ability to take Responsibility } & Control & $4.91(1.11)$ & $4.99(1.17)$ & $0.08(0.89)$ & 0.009 & $<0.001$ \\
\hline & Intervention & $4.85(1.08)$ & $5.32(1.15)$ & $0.46(0.95)$ & $<0.001$ & \\
\hline & $\mathrm{P}+$ & 0.206 & $<0.001$ & & & \\
\hline \multirow[t]{3}{*}{ Self-esteem (BASE scale) } & Control & $3.63(0.63)$ & $3.72(0.66)$ & $0.08(0.43)$ & $<0.001$ & $<0.001$ \\
\hline & Intervention & $3.62(0.64)$ & $3.93(0.69)$ & $0.31(0.52)$ & $<0.001$ & \\
\hline & $\mathrm{P}+$ & 0.424 & $<0.001$ & & & \\
\hline
\end{tabular}

+p-value for group effect; ++p-value for time effect; $¥$ Repeated measurements ANOVA. Effects reported include differences between the groups in the degree of change over the follow-up period

Table 4. Results of multiple linear regressions models for differences between the two study groups with dependent variables the change in questionnaire dimensions and self-esteem adjusted for demographic variables.

\begin{tabular}{lrrr}
\hline Change: & $\beta+$ & SE++ & $P$ \\
\hline Ability to control Verbal and Physical Aggressiveness & 0.22 & 0.04 & 0.001 \\
\hline Problem-Solving Ability & 0.38 & 0.05 & $<0.001$ \\
\hline Concentration of Attention & 0.42 & 0.06 & $<0.001$ \\
\hline Participation/Cooperation & 0.36 & 0.05 & $<0.001$ \\
\hline Empathy & 0.40 & 0.05 & $<0.001$ \\
\hline Emotions' Management & 0.36 & 0.06 & $<0.001$ \\
\hline Friendship skills & 0.22 & 0.04 & $<0.001$ \\
\hline Ability to control Victimization & 0.26 & 0.04 & $<0.001$ \\
\hline Emotions' Identification and Expression & 0.44 & 0.07 & $<0.001$ \\
\hline Use of Spoken and Written Language & 0.21 & 0.05 & $<0.001$ \\
\hline Ability to take Responsibility & 0.33 & 0.05 & $<0.001$ \\
\hline Self-esteem (BASE scale) & 0.17 & 0.03 & $<0.001$ \\
\hline
\end{tabular}

+ regression coefficient for the intervention versus the control group adjusted for gender, nationality, age, father's and mother's educational level, living with both parents, number of siblings, attendance of an integration class or receiving parallel support, re-attendance of the same grade, school hours (classic or all day) and number of class students; ++standard error 
better in Ability to control Verbal and Physical Aggressiveness, Concentration of Attention, Emotions' Management, and Ability to control Victimization. Moreover, there were significant differences in the degree of change of all dimensions between the two groups, with the intervention group students showing significantly greater improvement compared to the control group children.

Differences in the changes of the questionnaire dimensions between the two study groups after adjusting for gender, nationality, age, father's and mother's educational level, living with both parents in the same house, number of siblings, attendance of an integration class or having parallel support, re-attendance of the same grade, type of course (classic or all day), and number of students in class, are presented in table 4.

Regression analyses showed that children of the intervention group had significantly greater improvement of all their investigated skills post intervention as compared to controls.

Table 5 shows correlation coefficients between changes of all dimensions for the intervention group.

\section{Discussion}

The purpose of the presented study was to evaluate the effectiveness of "Steps for Life" Elementary Programme on students' personal and social skills as depicted in Personal and Social Skills Scale for Elementary Students Aged 7-9 (Kourmousi et al., 2017), and also on their self-esteem by the use of the BASE scale (Coopersmith \& Gilberts, 1982). All our hypotheses were confirmed.

At baseline both groups had similar scores in all investigated dimensions. Their post intervention scores revealed that the experimental group significantly improved all the targeted skills while the control one significantly improved their self-esteem, their participation/cooperation in class, their emotions' identification and expression, their friendship skills, their problem-solving ability, their ability to take responsibility, and their use of spoken and written language, but did not improve their concentration of attention, their emotions' management, their ability to control verbal and physical aggressiveness, and their ability to control victimization. This probably indicates that either the natural maturation and/or the Greek school regular curriculum possibly contribute to the first skills' improvement in students, but do not do much for the second ones.

Table 5. Pearson correlation coefficients between changes of all dimensions for the intervention group

\begin{tabular}{|c|c|c|c|c|c|c|c|c|c|c|c|}
\hline & & & & & & Change: & & & & & \\
\hline Change: & $\begin{array}{l}\text { Prob- } \\
\text { lem- } \\
\text { Solving } \\
\text { Ability }\end{array}$ & $\begin{array}{l}\text { Concen- } \\
\text { tration of } \\
\text { Attention }\end{array}$ & $\begin{array}{l}\text { Partici- } \\
\text { pation/ } \\
\text { Cooper- } \\
\text { ation }\end{array}$ & Empathy & $\begin{array}{l}\text { Emo- } \\
\text { tions' } \\
\text { Man- } \\
\text { age- } \\
\text { ment }\end{array}$ & $\begin{array}{l}\text { Friend- } \\
\text { ship } \\
\text { skills }\end{array}$ & $\begin{array}{l}\text { Ability } \\
\text { to } \\
\text { control } \\
\text { Victimi- } \\
\text { zation }\end{array}$ & $\begin{array}{l}\text { Emo- } \\
\text { tions' } \\
\text { Identi- } \\
\text { fication } \\
\text { and } \\
\text { Expres- } \\
\text { sion }\end{array}$ & $\begin{array}{l}\text { Use of } \\
\text { Spoken } \\
\text { and } \\
\text { Written } \\
\text { Lan- } \\
\text { guage }\end{array}$ & $\begin{array}{l}\text { Ability } \\
\text { to take } \\
\text { Respon- } \\
\text { sibility }\end{array}$ & $\begin{array}{c}\text { Self-es- } \\
\text { teem }\end{array}$ \\
\hline $\begin{array}{l}\text { Ability to } \\
\text { control } \\
\text { Verbal } \\
\text { and } \\
\text { Physical } \\
\text { Aggres- } \\
\text { siveness }\end{array}$ & 0.19 & 0.35 & 0.48 & 0.43 & 0.55 & 0.30 & 0.47 & 0.17 & 0.26 & 0.49 & 0.32 \\
\hline $\begin{array}{l}\text { Problem- } \\
\text { Solving }\end{array}$ & & 0.52 & 0.47 & 0.43 & 0.32 & 0.43 & 0.31 & 0.39 & 0.57 & 0.41 & 0.67 \\
\hline $\begin{array}{l}\text { Concen- } \\
\text { tration of } \\
\text { Attention }\end{array}$ & & & 0.63 & 0.37 & 0.41 & 0.31 & 0.26 & 0.24 & 0.42 & 0.37 & 0.52 \\
\hline $\begin{array}{l}\text { Participa- } \\
\text { tion/Coop- } \\
\text { eration }\end{array}$ & & & & 0.50 & 0.55 & 0.42 & 0.36 & 0.33 & 0.42 & 0.50 & 0.57 \\
\hline Empathy & & & & & 0.42 & 0.54 & 0.29 & 0.50 & 0.41 & 0.55 & 0.56 \\
\hline $\begin{array}{l}\text { Emotions' } \\
\text { Manage- } \\
\text { ment }\end{array}$ & & & & & & 0.32 & 0.33 & 0.25 & 0.30 & 0.48 & 0.45 \\
\hline $\begin{array}{l}\text { Friendship } \\
\text { skills }\end{array}$ & & & & & & & 0.40 & 0.46 & 0.43 & 0.39 & 0.58 \\
\hline $\begin{array}{l}\text { Ability to } \\
\text { control } \\
\text { Victimiza- } \\
\text { tion }\end{array}$ & & & & & & & & 0.23 & 0.29 & 0.36 & 0.36 \\
\hline $\begin{array}{l}\text { Emotions' } \\
\text { Identifica- } \\
\text { tion }\end{array}$ & & & & & & & & & 0.35 & 0.34 & 0.46 \\
\hline $\begin{array}{l}\text { Use of } \\
\text { Spoken } \\
\text { and } \\
\text { Written } \\
\text { Language }\end{array}$ & & & & & & & & & & 0.44 & 0.55 \\
\hline $\begin{array}{l}\text { Responsi- } \\
\text { bility }\end{array}$ & & & & & & & & & & & 0.51 \\
\hline
\end{tabular}


The degree of the improved skills' change was also found to differ significantly between the two groups, with the intervention group exhibiting higher improvement in all dimensions. Analytically, regarding each targeted skill, our results lead as to the following comparisons and comments:

Self-esteem is a trait widely targeted in social-emotional learning programmes. Focusing on self-esteem is considered a core element of mental health promotion, as Mann, Hosman, Schaalma and De Vries state (2004).In our study, the experimental-group students exhibited significantly higher improvement in it post intervention. Our finding confirmed the findings of "Steps for Life" K-Programme evaluation study (Kourmousi, Salagianni, Merakou, Tzavara, \& Koutras, 2017; Kourmousi, 2012), as well as those of several other researchers (e.g. Ghilay, \& Ghilay, 2015; O'Mara et al., 2006; Haney \& Durlac, 1998; Elias, Gara, Schuyler, Branden-Muller \& Sayette, 1991) who concluded that self-esteem can be significantly improved through social-emotional skills' enhancement interventions. In any case, we believe that when knowledge is produced by the student, which is the situation in the above mentioned programme, he/she results in feeling self-efficient; research has shown that cognitive-behavioural approaches change self-esteem in children and adolescents (Haney \& Durlak, 1998). However, unconditional positive regard and empathy, namely the humanistic approach elements of the programme, also encourage positive self-regard (Kahn \& Rachman, 2000).Concentration of attention - a skill not commonly targeted in similar interventions - improved significantly higher in our intervention group. Although we did not come upon such a finding in other studies, the previous research of the effectiveness of the "Steps for Life" K-Programme (Kourmousi, Salagianni, Merakou, Tzavara, \& Koutras, 2017; Kourmousi, 2012) confirms the fact that this programme enhances the skill of concentration, possibly because a whole lesson is devoted to it and/or also because of the dissemination of the learning in the formal and hidden curriculum, where every real-life distraction is viewed as an opportunity for practice; besides, attempt and repetition are proposed by the social learning theory (Bandura, 1997) as important determinants of learning.

Participation and cooperation of the students during class was significantly more improved in the experimental group students, corroborating the finding of the study on "Steps for Life" K-Programme effectiveness (Kourmousi, Salagianni, Merakou, Tzavara, \& Koutras, 2017; Kourmousi, 2012). Our search of the existing literature did not reveal similar results of other such interventions, since participation and cooperation do not seem to constitute targeted skills of theirs. However, several studies and me ta-analyses have shown interventions' positive impact on students' academic achievements in general (Ashdown \& Bernard, 2012; Brackett, Rivers, Reyes \& Salovey, 2012; Diekstra \& Gravesteijn, 2008; Durlak et al., 2011; Payton et al., 2008; Zins, 2004; NRCIM, 2000). Again, observation and imitation, which are proposed by the social learning theory (Bandura, 1997) as important learning factors, could be the cause of the change.

Emotions' identification and expression, as well as emotions' management were higher improved in the intervention students, a finding also observed in the "Steps for Life" K-Programme effectiveness study (Kourmousi, Salagianni, Merakou, Tzavara, \& Koutras, 2017; Kourmousi, 2012). These skills, however, seem to be widely targeted by the majority of similar interventions, most of which appear to achieve their goals (e.g. Domitrovich, Cortes \& Greenberg, 2007: Gansle, 2005: Hawkins, Smith \& Catalano, 2004). Psychoanalytic elements help support emotions' identi- fication (Cho, 2009; Kusché, 2002; Britzman, 1998) while cognitive ones help in emotional management (Nelis, Quoidbach, Mikolajczak \& Hansenne, 2009).

Ability to control verbal and physical aggressiveness and ability to control victimization were significantly more improved in the experimental group, similarly to the finding of the study on the "Steps for Life" K-Programme effectiveness (Kourmousi, Salagianni, Merakou, Tzavara, \& Koutras, 2017; Kourmousi, 2012). These skills, widely met in bullying prevention programmes appear to be targeted and achieved by other researchers as well (e.g. Powell \& Dunlap, 2009; Catalano et al., 2004; McMahon, Washburn, Felix, Yakin \& Childrey, 2000; Aiken, West, Schwalm, Carroll \& Hsiung, 1998). This fact shows that school-based programmess can tackle aggression and victimization effectively by social and emotional skills enhancement, as indicated by WHO (2004b, p. 35). More specifically, cognitive and ecological approaches have been proven to be significantly effective in bullying prevention skills (e.g. Eron, L., Huesmann, R., Spindler, A., Guerra, N., Henry, D. \& Tolan, P. (2002), since social-cognitive underpinnings of aggression have been located (Huesmann, 1998) and the impact of multiple contexts (e.g. teachers, peers, families) has been clarified (Weissberg \& Greenberg, 1997).

Empathy improved significantly higher in the elementary students who attended the "Steps for Life" curriculum, as had happened in the kindergarten ones, with the previous unit of the programme (Kourmousi, Salagianni, Merakou, Tzavara, \& Koutras, 2017; Kourmousi, 2012). Empathy seems to be a goal which several social skills interventions seek to achieve, with quite many of them succeeding in doing so (e.g. de Acedo Lizarraga, Ugarte, Cardelle-Elawar, Iriarte, \& de Acedo Baquedano, 2003; Committee for Children, 2002; Webster-Stratton \& Hammond, 1997; Goldstein \& Glick, 1994), proving that it is an ability that can be ameliorated in students by cognitive interventions (e.g. Gerdes, Segal, Jackson \& Mullins, 2011) and by the use of role-playing (Hojat, 2009; Feshbach, 1975).

Friendship skills were higher improved in the intervention students. The "Steps for Life" Elementary Programme gives emphasis on the specific skills' teaching, by a) friendship promoting activities like story-reading and club-founding, b) the use of appropriate games such as the "secret friend" or the "wheel of friendship", and c) by the role-playing steps for ways of joining a groups of friends. Friendship skills and social competence skills in general are widely sought by most similar interventions, which also appear to achieve their goals (e.g. Griffin, Andrew, Caldarella, Sabey, \& Heath, 2017; Baker-Henningham, Scott, Jones \& Walker, 2012; Bierman et al., 2010; Greenberg et al., 2003). Specifically, cognitive approaches (e.g. Mize \& Ladd, 1990; Ladd \& Mize, 1983), systemic approaches (e.g. Bellini), and ones that include role-playing (Rao, P. A., Beidel, D. C., \& Murray, M. J. 2008; Asher, Parker, \& Walker, 1998) have been found to enhance children's friendship and social skills.

Problem-solving ability was significantly more improved in the experimental group, as also observed in the effectiveness study of "Steps for Life" K-Programme (Kourmousi, Salagianni, Merakou, Tzavara, \& Koutras, 2017; Kourmousi, 2012). Not many mental health promotion and lifeskills programmes target problem solving ability, to our knowledge. Our search of the relevant literature revealed similar positive outcomes of the "I can Problem Solve" programme evaluation (Shure \& Spivack, 1982), confirming the fact that problem-solving can be taught to and learned by students, through structured cognitive school approaches (Shure \& Spivack, 2008). 
Ability to take responsibility, was higher improved in the presented study's intervention students. Though no specific lesson of the investigated programme was dedicated to this ability, addressing the issue of truth and lying and a lesson about dealing with guilt might have contributed to this improvement. Moreover, the humanistic approach's unconditional acceptance of the students by their teachers, combined with the lack of criticism could also be factors which led to this change. The literature search on similar studies did not reveal similar results; ability to take responsibility does not seem to consist a goal for most social-emotional skills' programmes, despite Elias' and Schwab's, work (2006) which depicts responsibility as a significant social-emotional learning skill, and despite Dede's work (2010) which characterizes it as an important 21st century skill. Curiously, there are impressively more studies teaching responsibility taking through physical education activities (e.g. Quay \& Peters, 2008; Wright \& Burton, 2008; Hellison, 2003).

Finally, the use of spoken and written language improved significantly higher in the students who attended the "Steps for Life" programme. This finding is compatible with the ones of other similar studies which have shown that the enhancement of social and emotional skills in students results in ameliorating their academic performance as well (Babalis, Tsoli, Artikis, Mylonakou-Keke, \& Xanthak ou, 2013; Ashdown \& Bernard, 2012; Brackett et al., 2012; Durlak et al., 2011; Diekstra \& Gravesteijn, 2008; Payton et al., 2008; Zins, 2004; NRCIM, 2000).

Overall, our evaluation revealed a positive effect of the "Steps for Life" programme in the enhancement of personal and social skills in elementary students.

\section{Implications of The Study}

The study builds on the existing literature regarding the effectiveness of similar interventions, by corroborating the findings of other researchers and also by investigating the specific intervention's impact on skills which have not been quite investigated (e.g. concentration of attention, responsibility taking).

Concerning Greece, the study will even help in the consolidation of the understanding of the importance of conducting evaluation research, in order for the educators to have evidence-based approaches to use in their teaching. Moreover, it will help spread the perception that emotional skills can be taught by teachers who have not attended related courses during their undergraduate studies, with the guidance of evidence-based training and structured curricula.

\section{Limitations and Strengths of The Study}

The study has several strengths, with its large sample-size being a very important one. Also, the representation of urban, rural and industrial areas, as well as high, middle and low-income ones - according to the Hellenic Statistical Authority (2011) -, ensured the fact that all types of areas and all types of income were included. Furthermore, the fact that the study was conducted in Attica, the prefecture in which Greece's capital is located and in which $35,5 \%$ of the Greek population resides (Hellenic Statistical Authority, 2012), added further to the representativeness of the sample.

Apart from the large sample size and its representativeness, another strong point of the study was the monitoring and continuous evaluation of its implementation fidelity.
However, the study also had some weak points. The use of teachers as facilitators of the intervention programme and evaluators of the students' behaviors consists one, even though it is a tactic often used in universal school programmes' evaluations and adopted by several researchers, mostly due to the lack of financing (Ashdown \& Bernard, 2012; Brackett et al., 2012; Durlak et al., 2011; Diekstra \& Gravesteijn, 2008; Domitrovich, Cortes \& Greenberg, 2007; Mishara \& Ystgaard, 2006; Vazsonyi, Belliston \& Flannery, 2004).

Another weak point of the presented research is the lack of a follow-up study, which would investigate the sustainability of its results.

\section{Conclusions}

Our "'Steps for Life' Life" intervention verified our hypotheses, since all the targeted, taught and investigated personal and social skills, were significantly more improved in the experimental group of elementary students than the controls. The results confirm the findings of other researchers who concluded that universal mental health promotion school-based programmes which are structured and systemic, have a cognitive approach and a long duration, disseminate the knowledge of the taught skills in the formal and hidden curriculum, and also transfer it in the students' lives by involving their parents, can enhance socio-emotional skills and help prevent problem behaviors as well (Bear, Whitcomb, Elias, Blank, 2015; Durlak et al., 2011; Diekstra \& Gravesteijn, 2008; Payton et al., 2008; Wilson, Gottfredson \& Najaka, 2001; Durlak \& Wells, 1997). Concerning Greece, we hope to contribute in making teachers feel secure in teaching a subject for which they have not received any training during their under-graduate studies. We also hope that this type of education will soon be more generalized in both primary and secondary education, so that all students can profit from it and acquire the skills that will help them deal effectively with every-day difficulties, achieve better academic performance, and gain social and emotional well-being.

\section{Acknowledgements}

No financial support was provided for the conduct of the study. Therefore, the authors would like to thank all the elementary experimental and control groups' teachers who participated in the study without any financial benefit.

\section{Author Contributions}

NK and GM designed the study and conducted it, under the supervision of VK. NK, GM and VK also conducted the experiential training, with the help of $A M$ and $E C$, who organized it. AM and EC supervised the implementation of the programme. CT conducted the statistical analyses, with the help of KK. KK drafted the manuscript and AM together with all the authors reviewed its final form.

\section{Conflicts of Interest}

The authors declare no conflict of interest.

\section{References}

Aiken, L. S., West, S. G., Schwalm, D. E., Carroll, J. L., \& Hsiung, S. (1998). Comparison of a randomized and two quasi-experimental designs in a single outcome evaluation efficacy of a university-level remedial writing program. Evaluation Review, 22(2), 207-244. https://doi.org/10.1177/0193841X9802200203 
Arend, R., Gove, F. L., \& Sroufe, L. A. (1979). Continuity of individual adaptation from infancy to kindergarten: A predictive study of ego-resiliency and curiosity in preschoolers. Child Development, 950-959. http://www.jstor.org/stable/1129319

Ashdown, D. M., \& Bernard, M. E. (2012). Can explicit instruction in social and emotional learning skills benefit the social-emotional development, well-being, and academic achievement of young children? Early Childhood Education Journal, 39(6), 397-405. https://doi.org/10.1007/s10643-011-0481-x

Asher, S. R., Parker, J. G., \& Walker, D. L. (1998). 16 Distinguishing friendship from acceptance: Implications for intervention and assessment. The company they keep. Friendships in childhood and adolescence, 366.

Babalis, T., Tsoli, K., Artikis, C. T., Mylonakou-Keke, I., \& Xanthakou, Y. (2013). The impact of social and emotional learning programs on the emotional competence and academic achievement of children in Greek primary school. World Journal of Education, 3(6), 54. https://doi.org/10.5430/wje.v3n6p54

Baker-Henningham, H., Scott, S., Jones, K., \& Walker, S. (2012). Reducing child conduct problems and promoting social skills in a middle-income country: cluster randomised controlled trial. The British Journal of Psychiatry, 201(2), 101-108. DOI: 10.1192/ bjp.bp.111.096834

Bandura, A. (1997). Social Learning Theory. NJ, USA, Prentice Hall.

Barrett, P. M. (2004). FRIENDS for life! for children. Participant workbook and leaders manual. LJ Farrel \& PM Barrett, Child and Adolescent Mental Health, $12(2), 58-65$.

Bear, G. G., Whitcomb, S. A., Elias, M. J., Blank, J. C. (2015). SEL and schoolwide positive behavioral interventions and supports. In Durlak, J., Domitrovich, C., Weissberg, R.; Gullotta, T. (Eds) Handbook of Social and Emotional Learning (pp. 453-467) New York: The Guillford Press

Beelmann, A., \& Lösel, F. (2006). Child social skills training in developmental crime prevention: Effects on antisocial behavior and social competence. Psicothe$m a, 18(3), 603-610$.

Bellini, S. (2007). Building social relationships textbook edition: A systematic approach to teaching social interaction skills to children and adolescents with autism spectrum disorders and other social difficulties. AAPC Publishing.

Bierman, K. L., Coie, J. D., Dodge, K. A., Greenberg, M. T., Lochman, J. E., McMahon, R. J., \& Pinderhughes, E. (2010). The effects of a multiyear universal socialemotional learning program: The role of student and school characteristics. Journal of consulting and clinical psychology, 78(2), 156. http://dx.doi. org/10.1037/a0018607

Borba, M. (1989). Esteem Builders: A K-8 Self-esteem curriculum for improving student achievement, behavior and school climate. BL Winch \& Assoc./Jalmar Press, CA, USA.
Botvin, G. (1998). Life Skills Training: Promoting Health and Personal Development. NYC, USA, Princeton Health Press.

Botvin, G. J., Baker, E., Dusenbury, L., Botvin, E. M., \& Diaz, T. (1995). Long-term follow-up results of a randomized drug abuse prevention trial in a white middle-class population. Jama, 273(14), 1106-1112. DOI: 10.1001/jama.1995.03520380042033

Botvin, G. J., Griffin, K. W., Paul, E., \& Macaulay, A. P. (2003). Preventing tobacco and alcohol use among elementary school students through life skills training. Journal of Child \& Adolescent Substance Abuse, 12(4), 1-17. https://doi.org/10.1300/J029v12n04_01

Brackett, M. A., Rivers, S. E., Reyes, M. R., \& Salovey, P. (2012). Enhancing academic performance and social and emotional competence with the RULER feeling words curriculum. Learning and Individual Differences, 22(2), 218-224. https://doi. org/10.1016/j.lindif.2010.10.002

Britzman, D. P. (1998). Lost subjects, contested objects: Toward a psychoanalytic inquiry of learning. Suny Press.

Brown, R., \& Ogden, J. (2004). Children's eating attitudes and behaviour: a study of the modelling and control theories of parental influence. Health education research, 19(3), 261-271.

Catalano, R. F., Berglund, M. L., Ryan, J. A., Lonczak, H. S., \& Hawkins, J. D. (2004). Positive youth development in the United States: Research findings on evaluations of positive youth development programs. The annals of the American academy of political and social science, 591(1), 98-124. https://doi. org/10.1177/0002716203260102

Chimienti, G., \& Trilivas, S. (1994). Cognitive and Behavioral Effects of Social Skills Training on Greek and Lebanese Elementary-School Children. International Journal of Mental Health, 23(4), 53-68. https://doi.or g/10.1080/00207411.1994.11449293

Cho, K. (2009). Psychopedagogy: Freud, Lacan, and the psychoanalytic theory of education. Springer.

Clore, G. L., \& Jeffery, K. M. (1972). Emotional role playing, attitude change, and attraction toward a disabled person. Journal of personality and social psychology, 23(1), 105

Committee for Children. (2002) Second Step: A Violence Prevention Curriculum, Grades 1,2,3. Seattle, USA.

Coopersmith, S., \& Gilberts, R. (1982). Behavioral academic self esteem. Professional manual. Palo Alto, CA: Consulting Psychologist Press, Inc.

Corsini, R. (2017). Role playing in psychotherapy. Routledge.

Culbertson, F. M. (1957). Modification of an emotionally held attitude through role playing. The Journal of Abnormal and Social Psychology, 54(2), 230.

de Acedo Lizarraga, M. L. S., Ugarte, M. D., Cardelle-Elawar, M., Iriarte, M. D., \& de Acedo Baquedano, M. T. S. (2003). Enhancement of self-regulation, assertiveness, and empathy. Learning and Instruction, 13(4), 423-439. 
Dede, C. (2010). Comparing frameworks for 21st century skills. In Bellanca J. \& Brandt R. (Eds) 21st century skills: Rethinking how students learn, 20, 51-76. Bloomington, IN: Solution Tree Press, pp. 51-76.

Diekstra, R. F., \& Gravesteijn, C. (2008). Effectiveness of school-based social and emotional education programmes worldwide. Social and emotional education: An international analysis, 255-312. Available at: http://www.fundacionbotin.org/89dguuytdfr276ed_uploads/EDUCACION/ANALISIS\%20INTERNACIONAL/2008/ingles\%202008/Results2008. pdf

Domitrovich, C. E., Cortes, R. C., \& Greenberg, M. T. (2007). Improving young children's social and emotional competence: A randomized trial of the preschool "PATHS" curriculum. The Journal of primary prevention, 28(2), 67-91. https://doi.org/10.1007/s10935007-0081-0

Durlak, J. A., \& Wells, A. M. (1997). Primary prevention mental health programs for children and adolescents: A meta-analytic review. American journal of community psychology, 25(2), 115-152. DOI: 10.1023/A:1024654026646.

Durlak, J. A., Weissberg, R. P., Dymnicki, A. B., Taylor, R. D., \& Schellinger, K. B. (2011). The impact of enhancing students' social and emotional learning: A meta-analysis of school-based universal interventions. Child development, 82(1), 405-432. DOI: 10.1111/j.1467-8624.2010.01564.x.

Elias, M. J., Gara, M. A., Schuyler, T. F., Branden-Muller, L. R., \& Sayette, M. A. (1991). The promotion of social competence: Longitudinal study of a preventive school-based pro-gram. American Journal of Orthopsychiatry, 61(3), 409. http://dx.doi.org/10.1037/ h0079277

Elias, M. J., \& Schwab, Y. (2006). From compliance to responsibility: Social and emotional learning and classroom management. In Evertson C. \& Weinstein C. (Eds) Handbook of classroom management: Research, practice, and contemporary issues. New York, NY: Routledge, pp. 309-341.

Eron, L., Huesmann, R., Spindler, A., Guerra, N., Henry, D., \& Tolan, P. (2002). A cognitive-ecological approach to preventing aggression in urban settings: Initial outcomes for high-risk children. Journal of Consulting and Clinical Psychology, 70(1), 179.

Englander-Golden, P., Jackson, J. E., Crane, K., Schwarzkopf, A. B., \& Lyle, P. S. (1989). Communication skills and self-esteem in prevention of destructive behaviors. Adolescence, 24(94), 481.

Faggiano, F., Vigna-Taglianti, F. D., Versino, E., Zambon, A., Borraccino, A., \& Lemma, P. (2005). School-based prevention for illicit drugs' use. Cochrane Database Syst Rev, 2. DOI: 10.1002/14651858.CD003020. pub2.

Feshbach, N. D. (1975). Empathy in children: Some theoretical and empirical considerations. The Counseling Psychologist, 5(2), 25-30.

Flannery, D. J., Vazsonyi, A. T., Liau, A. K., Guo, S., Powell, K. E., Atha, H., Vesterdal, W. \& Embry, D. (2003). In- itial behavior outcomes for the peacebuilders universal school-based violence prevention program. Developmental psychology, 39(2), 292. http://dx.doi. org/10.1037/0012-1649.39.2.292

Forness, S. R., Serna, L. A., Kavale, K. A., \& Nielsen, E. (1998). Mental health and Head Start: Teaching adaptive skills. Education and Treatment of Children, 258-274. http://www.jstor.org/stable/42940507

Freiberg, H. J. (Ed.). (1999). School climate: Measuring, improving, and sustaining healthy learning environments. Psychology Press.

Gansle, K. A. (2005). The effectiveness of school-based anger interventions and programs: A meta-analysis. Journal of School Psychology, 43(4), 321-341. https:// doi.org/10.1016/j.jsp.2005.07.002

Geller, S. (1999). Al's pals: Kids making healthy choices. Richmond, VA: Wingspan LLC.

Gerdes, K. E., Segal, E. A., Jackson, K. F., \& Mullins, J. L. (2011). Teaching empathy: A framework rooted in social cognitive neuroscience and social justice. Journal of Social Work Education, 47(1), 109-131.

Ghilay, Y., \& Ghilay, R. (2015). ISMS: A new model for improving student motivation and self-esteem in primary education. International Electronic Journal of Elementary Education, 7(3), 383.

Goldstein, A. P., \& Glick, B. (1994). Aggression replacement training: Curriculum and evaluation. Simulation \& Gaming, 25(1), 9-26. https://doi. org/10.1177/1046878194251003

Greenberg, M. T., Domitrovich, C., \& Bumbarger, B. (2001). The prevention of mental disorders in school-aged children: Current state of the field. Prevention \& treatment, 4(1), 1a. http://dx.doi.org/10.1037/15223736.4.1.41a

Greenberg, M. T., Weissberg, R. P., O'brien, M. U., Zins, J. E., Fredericks, L., Resnik, H., \& Elias, M. J. (2003). Enhancing school-based prevention and youth development through coordinated social, emotional, and academic learning. American psychologist, 58(6-7), 466. http://dx.doi.org/10.1037/0003066X.58.6-7.466

Griffin Jr, A. A., Caldarella, P., Sabey, C. V., \& Heath, M. A. (2017). The effects of a buddy bench on elementary students' solitary behavior during recess. International Electronic Journal of Elementary Education, 10(1), 27-36.

Grossman, D. C., Neckerman, H. J., Koepsell, T. D., Liu, P. Y., Asher, K. N., Beland, K., Frey, K. \& Rivara, F. P. (1997). Effectiveness of a violence prevention curriculum among children in elementary school: A randomized controlled trial. Jama, 277(20), 16051611. DOI: 10.1001/jama.1997.03540440039030

Hahn, R., Fuqua-Whitley, D., Wethington, H., Lowy, J., Crosby, A., Fullilove, M., Johnson, R., Liberman, A., Moscicki, E., Price, L. \& Snyder, S. (2007). Effectiveness of universal school-based programs to prevent violent and aggressive behavior: A systematic review. American journal of preventive medicine, 33(2), S114-S129. https://doi.org/10.1016/j.amepre.2007.04.012 
Haney, P., \& Durlak, J. A. (1998). Changing self-esteem in children and adolescents: A meta-analytical review. Journal of clinical child psychology, 27(4), 423-433. https://doi.org/10.1207/s15374424jccp2704_6

Hatzichristou, C., \& Lianos, P. G. (2016). Social and emotional learning in the Greek educational system: An Ithaca journey. International Journal of Emotional Education, 8(2), 105.

Hawkins, J.D., Smith, B.H., \& Catalano, R.F. (2004). Social development and social and emotional learning. In Zins, J.E., Weissberg, R.P., Wang, M.C., Walberg H.J. (Eds) Building academic success on social and emotional learning: What does the research say? (pp. 135-150). New York, USA, Teachers College Press.

Hellenic Statistical Authority (2012). 2011 Census Data. Available at: http://www.alfavita.gr/sites/default/ files/attachments/apotelesmata_apografis_plithismou_katoikion_2011.pdf.

Hellenic Statistical Authority (2011). Demographic characteristics. Available at: http://www.statistics.gr/el/ statistics/-/publication/SAM03/2011 and http:// www.statistics.gr/documents/20181/1210503/ A1602 SAM04_DT_DC 00_2011_01_F_GR.pdf/2aa7132a-a7db-41fb-88f6-b6061d29dd13 in Greek.

Hellison, D. (2003). Teaching personal and social responsibility in physical education. In Silverman S., \& Ennis C. (Eds) Student learning in physical education: Applying research to enhance instruction. USA: Human Kinetics, pp. 241-254.

Herrman, H., Saxena, S., Moodie, R., \& World Health Organization. (2005). Promoting mental health: concepts, emerging evidence, practice: a report of the World Health Organization, Department of Mental Health and Substance Abuse in collaboration with the Victorian Health Promotion Foundation and the University of Melbourne. Available at: http://apps.who. int/iris/bitstream/10665/43286/1/9241562943 eng.pdf

Hills, A. P., King, N. A., \& Armstrong, T. P. (2007). The contribution of physical activity and sedentary behaviours to the growth and development of children and adolescents. Sports medicine, 37(6), 533-545.

Hojat, M. (2009). Ten approaches for enhancing empathy in health and human services cultures. Journal of health and human services administration, 412450.

Huesmann, L. R. (1988). An information-processing model for the development of aggression. Aggressive Behavior, 14, 13-24.

Kahn, E., \& Rachman, A. W. (2000). Carl Rogers and Heinz Kohut: A historical perspective. Psychoanalytic Psychology, 17(2), 294.

Kourmousi, N. (2012). Personal and Social Skills Training as a part of Health Education in Kindergarten. Published Doctoral dissertation, University of Ioannina, School of Educational Sciences, Department of Early Childhood Education. In Greek.
Available at https://www.didaktorika.gr/eadd/handle/10442/31671

Kourmousi, N. , Markogiannakis, G. , Lazaridis, I. , Kolliopoulou, K. , Papoutsaki, K. , Kounenou, K. , Tzavara, C. and Koutras, V. (2017) Validity and Reliability of an Adaptation of Personal and Social Skills Scale for K-Students for Use in 2.691 Greek Elementary Students. Creative Education, 8, 23522376. DOI: 10.4236/ce.2017.814161.

Kourmousi, N. , Salagianni, M. , Merakou, K. , Tzavara, C. and Koutras, V. (2017) Evaluation of the "Steps for Life" Personal and Social Skills Greek K-Curriculum. Creative Education, 8, 1912-1940. DOI: 10.4236/ ce.2017.812131.

Kusché, C. A. (2002). Psychoanalysis as prevention: Using PATHS to enhance ego development, object relationships, \& cortical integration in children. Journal of Applied Psychoanalytic Studies, 4(3), 283-301.

Kusché, C. A., \& Greenberg, M. T. (1994). The PATHS curriculum. Seattle, Washington, USA. Development Research and Programs.

Ladd, G. W., \& Mize, J. (1983). A cognitive-social learning model of social-skill training. Psychological review, 90(2), 127.

Lasky, S. (2000). The cultural and emotional politics of teacher-parent interactions. Teaching and Teacher Education, 16(8), 843-860.

Mann, M. M., Hosman, C. M., Schaalma, H. P., \& De Vries, N. K. (2004). Self-esteem in a broad-spectrum approach for mental health promotion. Health education research, 19(4), 357-372.

McMahon, S. D., Washburn, J., Felix, E. D., Yakin, J., \& Childrey, G. (2000). Violence prevention: Program effects on urban preschool and kindergarten children. Applied and preventive psychology, 9(4), 271-281. https://doi.org/10.1016/ S0962-1849(00)80004-9

McNaughton, D., Hamlin, D., McCarthy, J., Head-Reeves, D., \& Schreiner, M. (2008). Learning to listen: Teaching an active listening strategy to preservice education professionals. Topics in Early Childhood Special Education, 27(4), 223-231.

Meichenbaum, D. (1977). Cognitive behaviour modification. Cognitive Behaviour Therapy, 6(4), 185-192.

Merry, S., McDowell, H., Hetrick, S., Bir, J., \& Muller, N. (2004). Psychological and/or educational interventions for the prevention of depression in children and adolescents. Cochrane Database Syst Rev, 1(1). DOI: 10.1002/14651858.CD003380.pub2.

Ministry of Education and Religious Affairs (2003a). A cross thematic curriculum framework for compulsory education and analytical curricula for primary and secondary education. Official Gazette, Issue B, no 303 \& 304, 13-3-2003. Athens: Greek Pedagogical Institute.

Ministry of Education and Religious Affairs (2003b). A cross thematic curriculum framework for compulsory education. Published in Official Gazette, B(1366/18-10-2001), B(1373/18-10-2001), 
$B(1376 / 18-10-2001)$.

Mishara, B. L., \& Ystgaard, M. (2006). Effectiveness of a mental health promotion program to improve coping skills in young children: Zippy's Friends. Early Childhood Research Quarterly, 21(1), 110-123. https://doi.org/10.1016/j.ecresq.2006.01.002

Mize, J., and G.W. Ladd. (1990). A Cognitive-Social Learning Approach to Social Skill Training with Low-Status Preschool Children. Developmental Psychology, 26, 388-397.

Nelis, D., Quoidbach, J., Mikolajczak, M., \& Hansenne, M. (2009). Increasing emotional intelligence:(How) is it possible?. Personality and individual differences, 47(1), 36-41.

O'Mara, A. J., Marsh, H. W., Craven, R. G., \& Debus, R. L. (2006). Do self-concept interventions make a difference? A synergistic blend of construct validation and meta-analysis. Educational Psychologist, 41(3), 181-206. https://doi.org/10.1207/ s15326985ep4103_4

Payton, J., Weissberg, R. P., Durlak, J. A., Dymnicki, A. B., Taylor, R. D., Schellinger, K. B., \& Pachan, M. (2008). The Positive Impact of Social and Emotional Learning for Kindergarten to Eighth-Grade Students: Findings from Three Scientific Reviews. Technical Report. Collaborative for Academic, Social, and Emotional Learning (NJ1). Available at: https://eric.ed.gov /?id=ED505370.

Powell, D., \& Dunlap, G. (2009). Evidence-based social emotional curricula and intervention packages for children 0-5 years and their families (Roadmap to Effective Intervention Practices). Tampa, FL: University of South Florida.

Quay, J., \& Peters, J. (2008). Skills, strategies, sport, and social responsibility: reconnecting physical education. Journal of Curriculum Studies, 40(5), 601-626. https://doi.org/10.1080/00220270801886071

Rao, P. A., Beidel, D. C., \& Murray, M. J. (2008). Social skills interventions for children with Asperger's syndrome or high-functioning autism: A review and recommendations. Journal of autism and developmental disorders, 38(2), 353-361.

Rogers, C. (1998). The interpersonal relationship in the facilitation of learning. Taking Issue: Debates in Guidance and Counselling in Learning. London, Routledge (pp 196-208).

Roorda, D. L., Koomen, H. M., Spilt, J. L., \& Oort, F. J. (2011). The influence of affective teacher-student relationships on students' school engagement and achievement a meta-analytic approach. Review of Educational Research, 81(4), 493-529.

Shure, M. (2000). I can problem solve: An interpersonal cognitive problem-solving program. Champaign Illinois, USA, Research Press.

Shure, M. B., \& Spivack, G. (1982). Interpersonal problem $\square$ solving in young children: A cognitive approach to prevention. American Journal of Community Psychology, 10(3), 341-356. DOI: 10.1007/BF00896500.

Shure, M. B., \& Spivack, G. (2008). The problem-solving ap- proach to adjustment. Prevention in Human Services.

Staub, E. (1971). The use of role playing and induction in children's learning of helping and sharing behavior. Child Development, 805-816.

TACADE/Lions. (1990). Skills for the Primary School Child. Manchester, UK, TACADE.

Tobler, N. S., Roona, M. R., Ochshorn, P., Marshall, D. G., Streke, A. V., \& Stackpole, K. M. (2000). School-based adolescent drug prevention programs: 1998 meta-analysis. Journal of primary Prevention, 20(4), 275336. https://doi.org/10.1023/A:1021314704811

Triliva, S., Anagnostopoulou, T., \& Vleioras, G. (2014). Sensitizing Children to the Social and Emotional Mechanisms involved in Racism: a program evaluation. International Journal of Emotional Education, 6(2).

UNESCO (2004). United Nations Decade of Education for Sustainable Development: Draft International Implementation Scheme (IIS). United Nations Educational, Scientific and Cultural Organization, Paris.

Vazsonyi, A. T., Belliston, L. M., \& Flannery, D. J. (2004). Evaluation of a School-Based, Universal Violence Prevention Program: Low-, Medium-, and High-Risk Children. Youth Violence and Juvenile Justice, 2(2), 185206. https://doi.org/10.1177/1541204003262224

Webster-Stratton, C., \& Hammond, M. (1997). Treating children with early-onset conduct problems: a comparison of child and parent training interventions. Journal of consulting and clinical psychology, 65(1), 93. http://dx.doi.org/10.1037/0022-006X.65.1.93.

Weinstein, C. S. \& Mignano, A. J., Jr. (1993). Elementary classroom management: Lessons from research and practice. NY: McGraw-Hill.

Weissberg, R., Caplan, M., Sivo, P. (1989). A new conceptual framework for establishing school-based social competence promotion programmes. In Bond, L.S., Compas, B.E., (Eds) Primary prevention and promotion in the schools (pp. 255-296), Newbury Park CA, USA, Sage.

Weissberg, R. P., \& Greenberg, M. T. (1997). School and community competence-enhancement and prevention programs. In I. E. Sigel \& K. A. Renninger (Eds.), Handbook of child psychology: Vol. 6: Child psychology in practice (pp. 1-85). New York: Wiley.

Wilson, D. B., Gottfredson, D. C., \& Najaka, S. S. (2001). School-based prevention of problem behaviors: A meta-analysis. Journal of Quantitative Criminology, 17(3), 247-272. https://doi. org/10.1023/A:1011050217296

Wilson, S. J., \& Lipsey, M. W. (2007). School-based interventions for aggressive and disruptive behavior: Update of a meta-analysis. American Journal of Preventive Medicine, 33(2), S130-S143. https://doi. org/10.1016/j.amepre.2007.04.011

Wilson, S. J., Lipsey, M. W., \& Derzon, J. H. (2003). The effects of school-based intervention programs on aggressive behavior: a meta-analysis. Journal of Consulting and Clinical Psychology, 71(1), 136. http:// dx.doi.org/10.1037/0022-006X.71.1.136 
World Health Organization. (2002). Prevention and promotion in mental health. Geneva: World Health Organization.

World Health Organization. (2003). Skills for health: skillsbased health education including life skills: an important component of a Child-Friendly/Health-Promoting School. Geneva: World Health Organization.

World Health Organization. (2004a). Promoting mental health: Concepts, emerging evidence, practice: Summary report. Geneva: World Health Organization.

World Health Organization (2004b). Preventing violence: A guide to implementing the recommendations of the World report on violence and health. Geneva: World Health Organization.

WHO (2005). Herrman, H., Saxena, S., \& Moodie, R. Promoting mental health: concepts, emerging evidence, practice: a report of the World Health Organization, Department of Mental Health and Substance Abuse in collaboration with the Victorian Health Promotion Foundation and the University of Melbourne. Available at: http://apps.who.int/iris/bitstream/ handle/10665/43286/9241562943_eng.pdf;jsessionid=98D27C097428FF3478BEB6AD02677FBF? sequence $=1$.

World Health Organization. (2010). Violence prevention: the evidence. Malta: World Health Organization.

Wright, P. M., \& Burton, S. (2008). Implementation and outcomes of a responsibility-based physical activity program integrated into an intact high school physical education class. Journal of Teaching in Physical Education, 27(2), 138-154. https://doi. org/10.1123/jtpe.27.2.138

Zins, J. E. (Ed.). (2004). Building academic success on social and emotional learning: What does the research say? N.Y., USA, Teachers College Press. 